\title{
Arum nickelii Schott ve Monotipik Arisarum vulgare O.Targ.-Tozz Türleri Üzerinde Morfolojik ve Anatomik Bir Araştırma
}

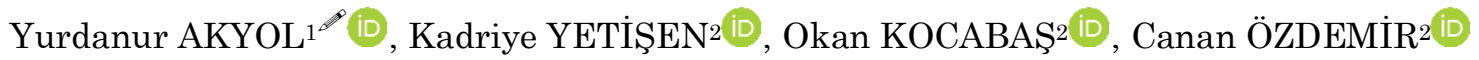 \\ ${ }^{1}$ Hasan Türek Anadolu Lisesi, ${ }^{2}$ Celal Bayar Üniversitesi, Fen-Edebiyat Fakültesi, Biyoloji Bölümü, Manisa \\ 凶:yurdanur45@gmail.com
}

\begin{abstract}
ÖZET
$\mathrm{Bu}$ çalışmada Araceae familyasından olan Arum nickelii Schott (Yılan yastığı) ve Arisarum vulgare O.Targ.-Tozz (Yılancıkotu) türlerinin anatomi ve morfolojileri araştırılmıştır. İncelenen türler spatanın birleşik olup olmaması bakımından birbirinden ayrılır. Anatomik çalışmalarda parafin metodu kullanılarak hazırlanan kök, skap ve yapraklar safranin-fast green ikili boyama serisinde boyanmıştır. Anatomik olarak tipik monokotil özellikleri gösteren bitkilerin diğer Araceae türlerinden ayırt edici bazı özelliklere sahip olduğu belirlenmiştir. Bu farklılıklar orijinal çizim ve fotoğraflarla gösterilmiştir.
\end{abstract}

\section{DOI:10.18016/ksudobil.297060}

Makale Tarihçesi

Geliş : 11.03.2017

Kabul : 15.05.2017

\author{
Anahtar Kelimeler \\ Araceae, \\ Arum nickelii, \\ Arisarum vulgare, \\ anatomi, \\ morfoloji
}

\section{Araştırma Makalesi}

\section{Morphological and Anatomical Studies on Arum nickelii Schott and Arisarum vulgare O.Targ.-Tozz Species}

\section{ABSTRACT}

In this study, aimed to investigate the morphology and anatomy of Arum nickelii Schott (Yılan yastığı) and Arisarum vulgare O.Targ.Tozz (Yllancikotu) belong to Araceae family. The plants are separated from each other according to whether spathe is united or divided. Anatomical sections were prepared using paraffin method and painted by double staining series safranin-fast green. It is observed that, plants containing typically features of monocotyl have distinguish features from other types of Araceae. These differences are illustrated with original drawings and photographs.

\section{Article History}

Received: 11.03.2017

Accepted: 15.05.2017

Keywords
Araceae,
Arum nickelii,
Arisarum vulgare,
anatomy,
morphology

Research Article

To Cited :Akyol Y, Yetişen K, Kocabaş O, Özdemir C 2018. Arum nickelii Schott ve Monotipik Arisarum vulgare O.Targ.-Tozz Türleri Üzerinde Morfolojik ve Anatomik Bir Araştırma. KSÜ Tarim ve Doğa Derg 21(2):239-245, DOI:10.18016/ksudobil.297060.

\section{GIRISS}

Yumrulu ya da rizomlu, genellikle tüysüz çok yıllık bitkilerden oluşan Araceae familyası Dünya genelinde 3000'den fazla tür içermektedir. Araceae familyasının doğal olarak Türkiye'de yayılış gösteren Arum L., Dracunculus Miller, Arisarum Miller, Biarum Schott, Lemna L., Spirodela Schleiden ve Eminium(Blume) Schott cinsleri bulunmaktadır (Davis, 1984; Davis ve ark., 1988; Anonim, 2017). Arum cinsi Türkiye'de 17 takson ile Arisarum cinsi ise monotipik olup sadece Arisarum vulgare türü ile temsil edilmektedir (Güner ve ark., 2012).
Ülkemizde yayılış gösteren Araceae familyasına ait olan bitkilerin yumrularının protein içerikleri ve zehirlilik etkilerinin araştırıldı ğ mevcuttur (Alpınar, 1985; Alpınar ve ark., 1996). Arisarum vulgare’nin içerdiği fenolik bileşikler bakımından antioksidant özellikli tıbbi bir bitki olduğu Kadri ve ark. (2013) tarafından ortaya atılmıştır. Kandemir (2008) Arum cinsine ait türlerin halk tıbbında kullanıldığını rapor etmiştir. Ayrıca Mayo ve ark. (1997)'nin Araceae familyasına ait türleri morfolojik, palinolojik, sistematik ve farmakolojik açıdan inceledikleri bir çalışma mevcuttur. Arum ve Arisarum cinsine ait türlerin anatomisi ile ilgili çok az 
sayıda çalışma mevcuttur (Kandemir, 2008; Mayo ve ark., 1997).

Yapılan literatür taramaları sonucunda Arum nickelii ve Arisarum vulgare türleri ile ilgili morfolojik ve anatomik çalışmaya rastlanmamıştır. Özellikle Arum türlerinin farklı ekolojik ortamlarda farklı özellikler göstermesi bitki teşhisinde zorluklara neden olmaktadır. Bu bakımdan anatomik çalışmalardan elde edilen bulgular, türlerin teşhisinde ayırt edici özellik olarak kullanılabilir. Türlerin anatomik yapılarının ortaya konulması farmasotik alanındaki çalışmalar için de kaynak oluşturacaktır.

\section{MATERYAL ve METOT}

Bitki örnekleri, arazi çalışmalarında yayılış gösterdiği doğal populasyonundan çiçeklenme mevsiminde toplandl. Arum nickelii türüne ait örnekler Nisan ayında, B1 karesindeki İzmir ilinden, Arisarum vulgare türüne ait örnekler ise Haziran ayında Spil Dağı Milli Parkı'ndan toplandı. Türlerin yayılış alanı Batı Anadolu'dur (Davis, 1984, Şekil 1).

Araziden toplanan taze bitki örneklerinin bir kısmı morfolojik çalışmalarda kullanıldı. Türlerin tayini "Flora of Turkey" adlı esere göre yapıldı (Davis ve ark., 1984, 1988; Güner ve ark., 2000). Morfolojik incelemeleri yapılan örnekler preslenerek herbaryum materyali haline getirildi ve Manisa, Celal Bayar Üniversitesi Herbaryumu'na konuldu. Taze bitki örneklerinin bir kısmı da anatomik incelemelerde kullanılmak üzere \% 70 'lik alkolde fikse edildi. Kök, skap ve yaprak enine kesitleri için parafin metodu kullanıldı (Algan, 1981). Rotary mikrotom sayesinde 10-15 p'luk enine kesitler alınıp safranin ve fast-green ile boyandı. Boyanan kesitler Leica marka kameralı mikroskop ile fotoğraflandırıldı.

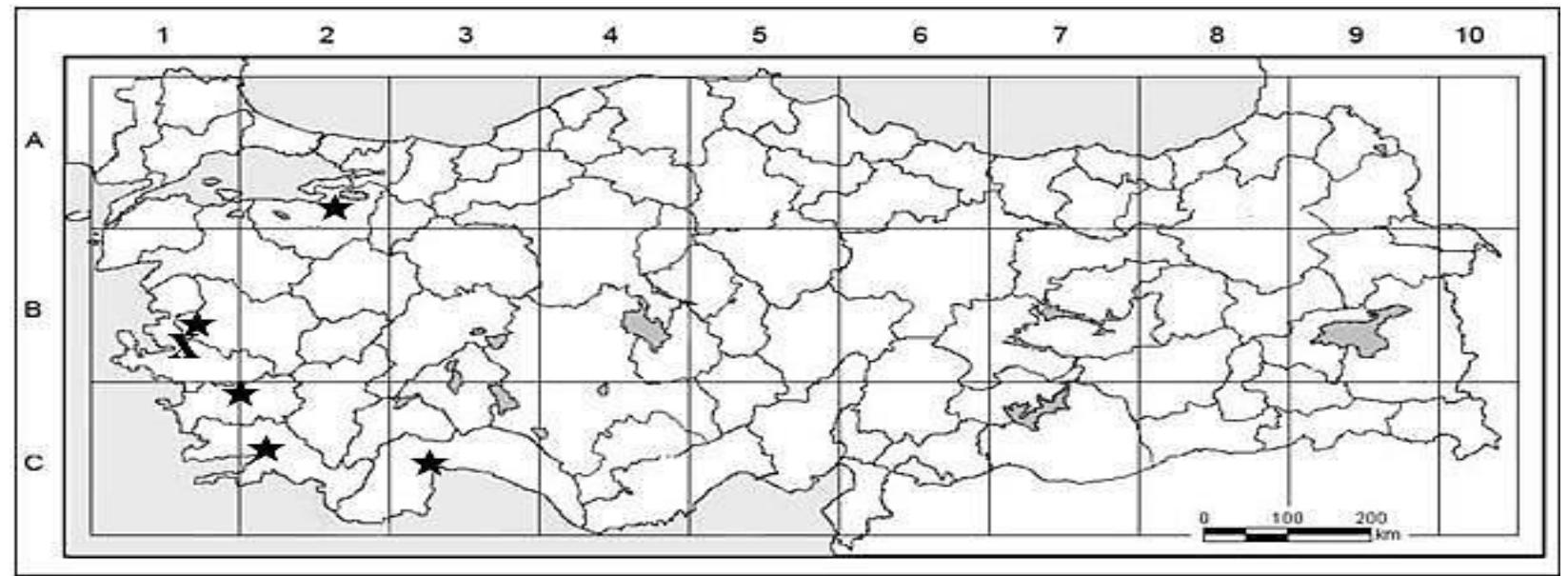

Şekil 1. Arum nickelii (x) ve Arisarum vulgare (*) taksonlarının Türkiye'deki yayılışı

Morfolojik çalışmalarda elde edilen bulgular Davis'in Flora of Turkey adlı eserindeki bulgular ile karşılaştırıldı. Anatomik çalışmalarda elde edilen bulgular ise Araceae familyasina ait türlerin anatomileri ile karşılaştırılmıştır (Davis ve ark., 1984, 1988; Güner ve ark., 2000).

\section{BULGULAR ve TARTIŞMA Morfolojik Bulgular}

Arum nickeli: Spatanın kenarları tabanda birbiri üzerine binmiş olup birleşik değildir. Spata 15-29 x 5.5-10 cm, içte yeşilimsi beyaz renkli, kalın ve etli olan başak şeklindeki çiçek 9-17 cm, spatanın yarısı uzunluktadır. Dişi çiçek zonu yaklaşık 19-25 mm; alt steril kısım 2-2.5 mm; erkek çiçek zonu 5-6 x 6.5-10 $\mathrm{mm}$; üst steril zon 6-8.5 mm. Steril filamentler sarımsibeyaz, altta 6-7 mm, üstte yaklaşık $6 \mathrm{~mm}$. Appendiks (uzantı) saplı ve 7-12.5 cm uzunluğunda, sap topuz şeklindeki üst kısma doğru aniden genişleyen şekilde, topuz geniş yapılı genellikle koni şeklinde $3.5-10.5 \mathrm{~cm}$ x 6-13 mm'dir. Yeşilimsi sarı ya da koyu kahverengi, yoğun beyaz kabarcıklıdır. Bitkinin yumrusu yatay, yaprak sapları 25-45 cm uzunluktadır. Yaprak ayası geniş bir ok şeklinde, yaklaşık olarak 23 x $20 \mathrm{~cm}$, koyu yeşil, soluk lekeli, geniş yan lobları bulunan dar ve sivri uçlu ve soluk damarlıdır. Skapa ise $13-15 \mathrm{~cm}$ uzunluğundadır.

Arisarum vulgare: Spatanın (büyük brakte) kenarları tabanda birleşik olup tüp şeklindedir. Spatanın üst kısmı koyu yeşil veya donuk morumsu kahverengidir. Tuberler yumurtamsıdır. Yapraklar uzun, mor benekli ve dik saplıdır. Skap 15-17 cm, dik ve mor beneklere sahiptir, alt kısmı beyazımsı veya soluk yeşil ve koyu yeşil veya morumsu renkli olup, boyuna çizgilidir. Meyve üzümsü yapıda olup küremsi şekildedir (Şekil 2). 

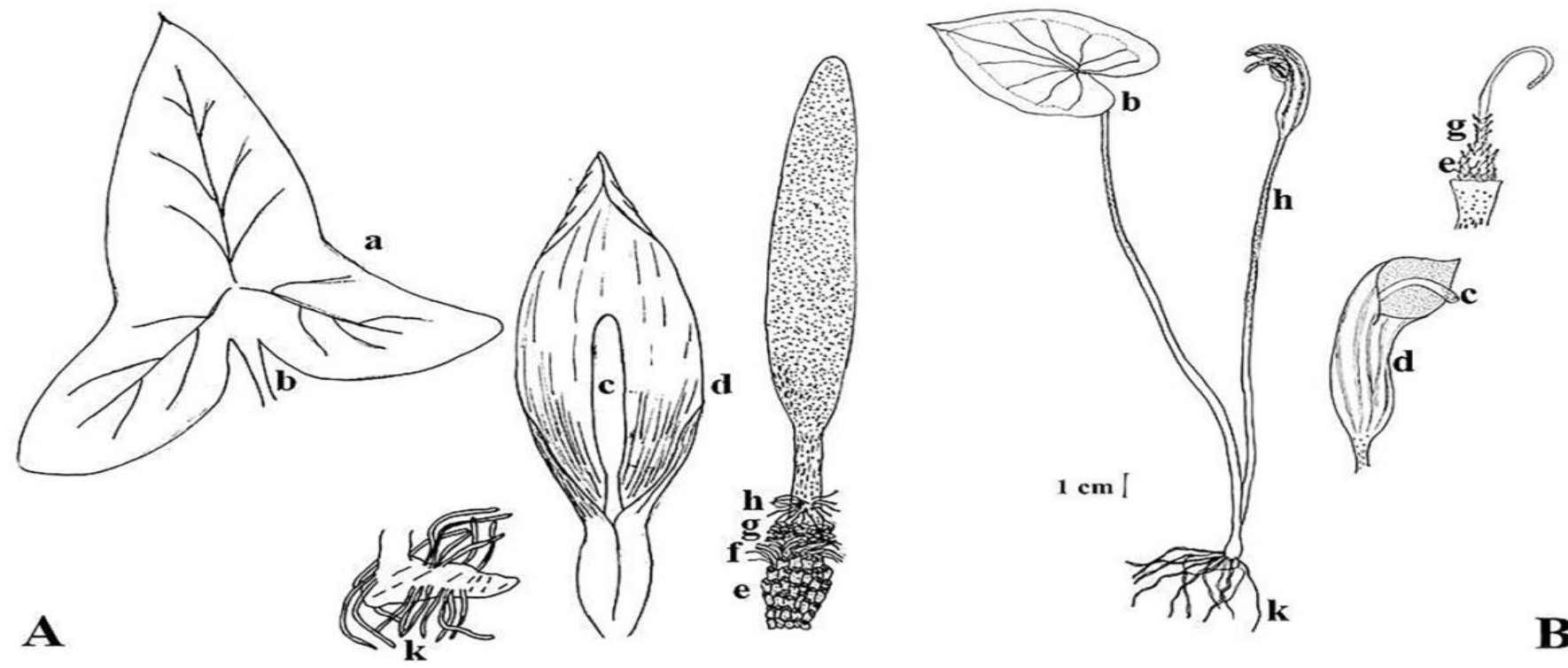

Şekil 2. Arum nickelii (A) ve Arisarum vulgare (B)'nin morfolojik yapıları; a: yaprak, b: petiyol, c: spadiks, d: spata, e: dişi çiçek zonu, f: alt steril zon, g: erkek çiçek zonu, h: üst steril zon, 1: appendiks (uzantı), k: yumru

\section{Anatomik Bulgular}

Arum nickeli: Kök enine kesitinin en dışında tek sıralı epidermis tabakası bulunmaktadır. Epidermisin dışında kutikula tabakası yer almaktadır. Korteks parankiması 10-13 hücre siralı olup, endodermisi oluşturan hücrelerin çeperlerinde kalınlaşma gözlenmemiştir. Endodermisin hemen altında tek sıralı ince çeperli perisikl tabakası yer almaktadır. Kökte 7-8 ksilem kolu bulunmaktadır. Kesitin merkezinde geniş çaplı birkaç metaksilem mevcuttur (Şekil 3 A, B). Skapa enine kesitine göre en dişta kutikula tabakası ayırt edilmektedir. Kutikula tabakasının altında tek sıralı ve hücreleri düzgün dikdörtgen şekilli olan epidermis tabakası bulunmaktadır. Epidermisin altında belirli aralıklarla dizilmiş kollenkima hücreleri yer alır. Korteks tabakası çeperleri ince, parankimatik ve hücreler arası boşluklara sahip olmayan 4-5 hücre sirasından oluşmaktadır. Küçük kollateral iletim demeti dairesel bir düzende 2 sıra halinde siralıdır. İletim demetlerinde ksilem, floeme göre daha geniş bir alanı kaplamaktadır. Gövdenin merkezinde çeperleri ince, hücreler arası boşluklara sahip normal parankima hücrelerinin doldurduğu öz bölgesi mevcuttur. Yaprak enine kesitinin her iki yüzeyinde kutikula tabakasının altında bir sıralı epidermis tabakası bulunur. Mezofil tabakasında tek siralı palizat parankimasından sonra sünger parankiması bulunur. Ayrıca bu tabakada belirli aralıklarla geniş hücreler arası alanlar bulunmaktadır. Mezofilde rafit demetlerine rastlanmıştır. İletim demetleri mezofil tabakasını orta kısmında düzenli ve sık aralıklarla sıralanmışlardır. Yaprağın her iki yüzeyinde de stomalar yer almaktadır (Şekil 3E, F).

Arisarum vulgare: Kök enine kesitlerinde tek siralı epidermisin altında düzensiz dizilmiş ve hücreler arası boşlukları bulunan korteks tabakası yer alır. Merkezi silindirin etrafı kaspari şeklinde çeperleri kalınlaşmış endodermis ile örtülüdür. İçte 3-4 adet metaksilem ve 5 adet ksilem kolu bulunmaktadır (Şekil 4 A, B). Skap enine kesitinde en dışta ince bir kutikula tabakası bulunmaktadır. Kortekste epidermisin altında küme şeklinde kollenkimatik hücreler ve yer yer rafit kristalleri bulunmaktadır. İletim demetleri 4 halka halinde sıralanmış olup öz bölgesindeki hücrelerin duvarları parçalanmıştır (Şekil 4 C, D, F). Yaprak enine kesitlerinde adaksiyal epidermis hücreleri abaksiyal epidermis hücrelerinden geniştir. Mezofilde aerenkima boşlukları bulunmakta olup, palizat ve sünger parankiması ayrımı gözlenmemiştir (Şekil $4 \mathrm{E}$ ). 

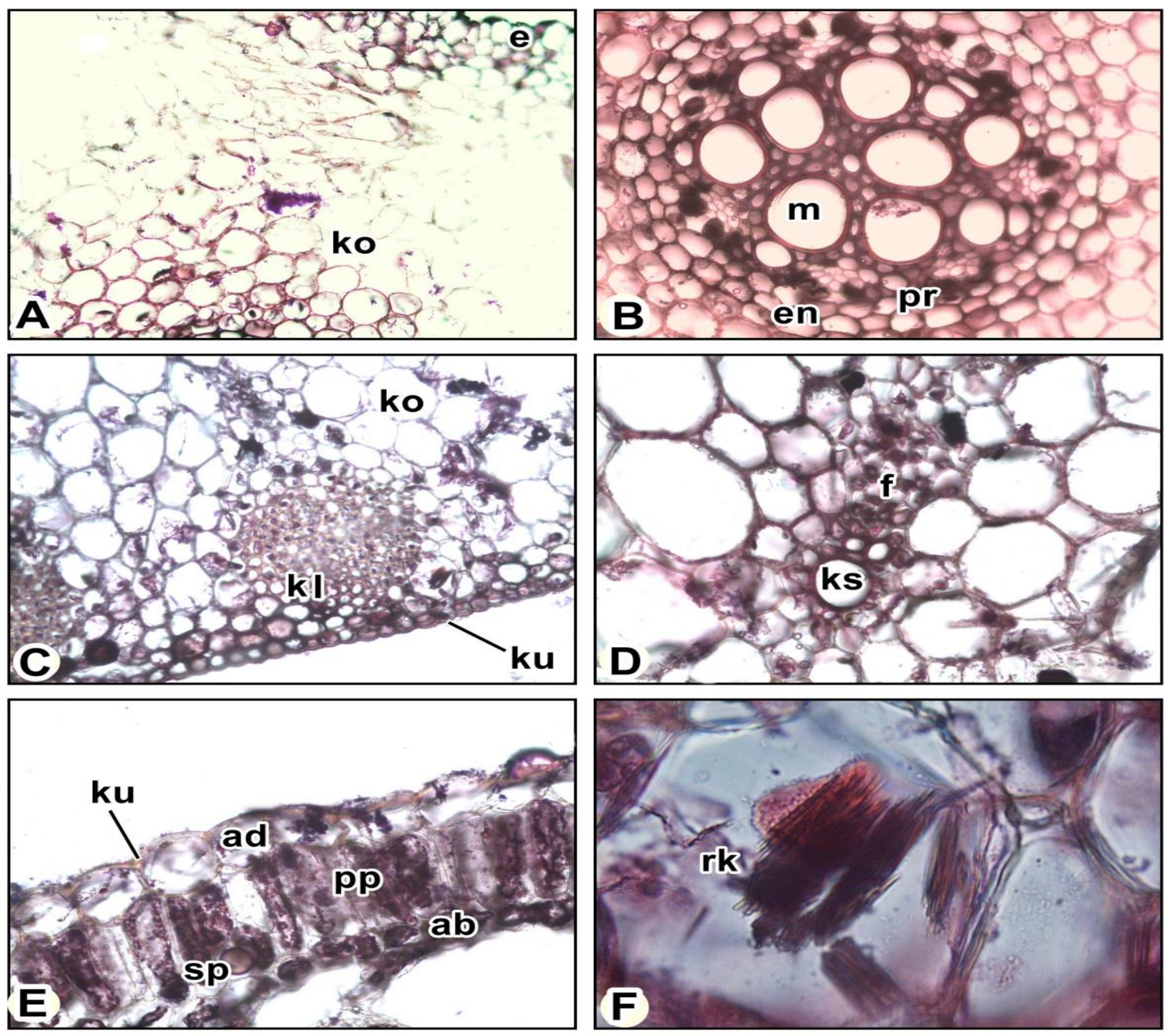

Şekil 3. Arum nickelii nin kök (A-B), skap (C), skapa ait iletim demeti (D) ve yaprak (E-F) enine kesitleri; e: epidermis, en: endodermis, f: floem, id: iletim demeti, kl: kollenkima, ko: korteks, ku: kutikula, ks: ksilem, m: metaksilem, pp: palizat parankiması, pr: periskl, sp: sünger parankiması, rk: rafit kristalleri. 

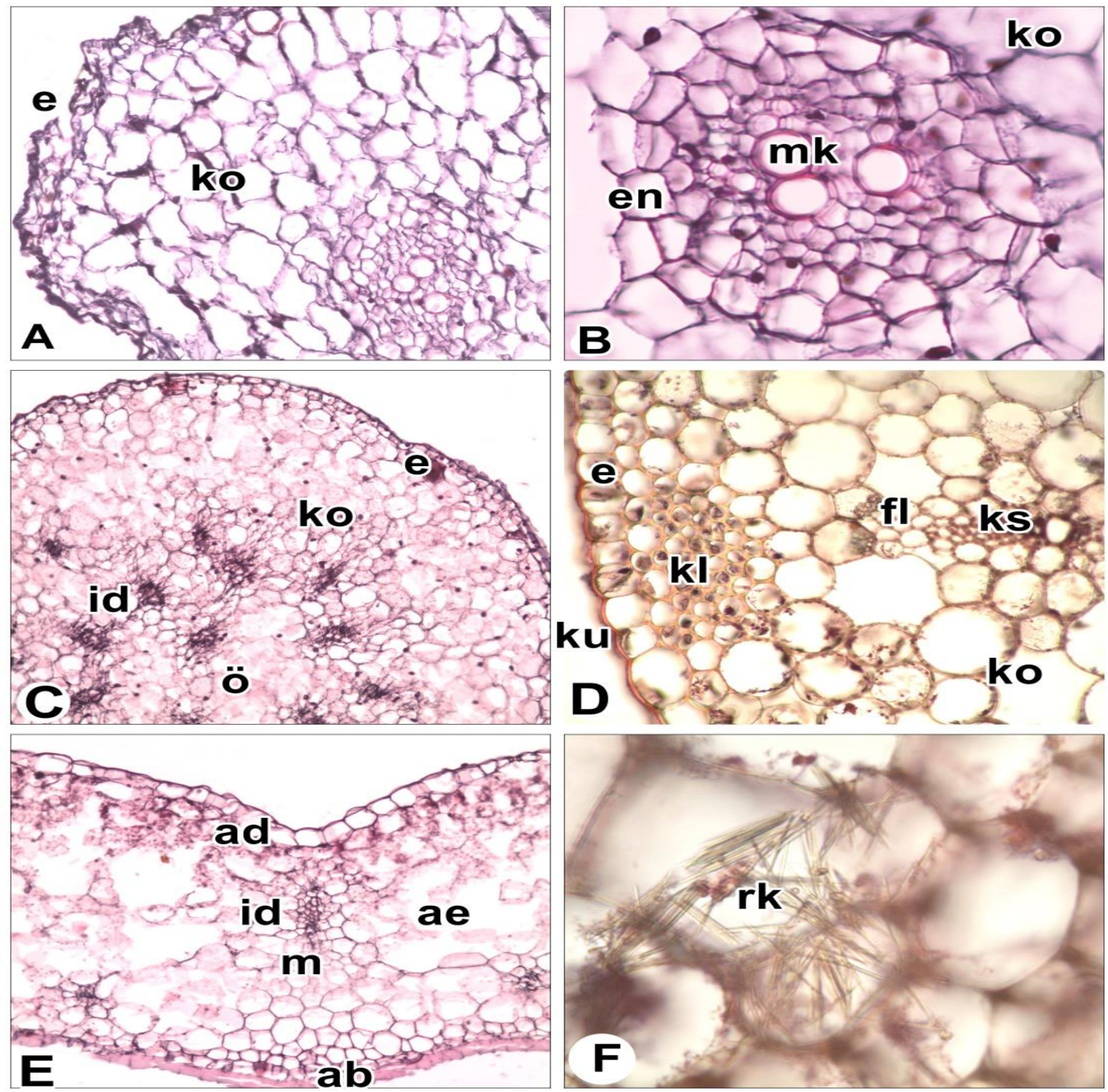

Şekil 4. Arisarum vulgare' nin kök (A-B), skap (C-D) ve yaprak (E) enine kesitleri ve rafit kristalleri (F); ab: abaksiyal epidermis, ad: adaksiyal epidermis, ae: aerenkima, e: epidermis, en: endodermis, f: floem, id: iletim demeti, ks: ksilem, ko: korteks, kl: kollenkima, ku: kutikula, mk: metaksilem, m: mezofil, id: iletim demeti.

\section{SONUÇ}

Çalışmamızda Arum nickelii ve monotipik Arisarum vulgare türlerinin morfolojik ve anatomik özellikleri araştırılmıştır. Morfolojik incelemelerde spatanın ayrık ya da birleşik oluşu iki cins için ayırt edici özelliklerdendir. Arum nickeliïnin yaprak saplarının skaptan uzun olması ve yumrunun yatay oluşu karakteristik özelliklerdendir. Morfolojik karakterler genel olarak Davis (1984)'in tanımiyla uyum göstermektedir.

Anatomik incelemelerde ise kök enine kesitinde Arum nickelii de endodermiste kalınlaşma gözlenmemiştir.
Her iki türde kök enine kesitlerinin merkezinde çok sayıda büyük metaksilem ve ksilem kolları bulunmaktadır. Skap enine kesitlerinde her iki türde de epidermisin altında köşe kollenkiması küme seklinde yer almaktadır. Benzer şekilde Mayo ve ark. (1997), Syngonium (Birdsey, 1955), Dieffenbachia (Tieghem, 1867), Aglaonema, Asterostigma, Homalomena, Philodendron, Schismatoglottis, Spathantheum ve Zantedeschia cinslerine ait türlerde de gövdede korteksin dış kısmında kollenkimanın bulunduğunu belirtmişlerdir. Anatomik çalışmalarda gözlenen rafit kristallerinin sistematik ve filogenetik 
çalışmalarda türler arası karışıklığı gidermek için önemli ve değişmeyen karakterler olduğu belirtilmiştir. Kristallerin şekli ve bitkide bulunduğu kısımlar çok önemlidir (Metcalfe ve Chalk, 1983; Yentür, 1995; Fahn, 1990; Selvi ve ark., 2008). Çalışmamızda rafit kristalleri çoğunlukla Arisarum vulgare'nin skapında, rafit demetleri de Arum nickeliïnin yapraklarında gözlenmiştir. Araştırmacılar Araceae familyasının mezofil dokusunda siklıkla druz ve rafit kristallerini gözlemişler hatta diğer kristallerinde bulunabileceğini not etmişlerdir (Genua and Hillson, 1985; Mayo ve ark., 1997; Keating, 2003, 2004). Yaprak mezofilleri Arum nickeliide bifasiyal olup, Arisarum vulgare'de ise unifasiyaldir. Dalitzsch (1886), Araceae familyasının mezofillerinin çoğunlukla bifasiyal olduğunu, izobilateral yaprakların ise nadiren görüldügünü Anthurium ve Montrichardia cinslerine ait bazı türlerde sünger parankimasının neredeyse hiç bulunmadığı, palizatın ise tek tip yapıda olduğunu belirtmiştir. Kandemir (2008), Ordu ve çevresinde yayılış gösteren Arum cinsine ait türlerin anatomilerini incelediği çalışmasında, Arum orientale Bieb. ve $A$. elongatum Steven subsp. elongatum türlerinin kök enine kesitlerinde endodermiste kaspari şeridi şeklinde çeper kalınlaşmasının bulunduğunu, yapraklarının bifasiyal olduğunu ve mezofillerinde geniş havalandırma boşlukları (aerenkima) ve rafit kristallerinin yer aldığını belirtmiştir. İncelediğimiz türlerin bu çalışmada elde edilen bulgularla benzerliklerinin olması yaninda gövdede kollenkimatik hücreler bulunması gibi farklı bulgular da yer almaktadır. Arum cinsine ait türlerin anatomisi ile ilgili rastlanan çok az sayıda çalışma olması bakımından incelenen türler $A$. orientale ve $A$. elongatum subsp. elongatum türlerinin anatomik bulguları ile karşılaştırılmıştır (Çizelge 1).

Çizelge 1. İncelenen türlerin diğer Arum cinsine ait türlerle (Kandemir, 2008) karşllaştırılması

\begin{tabular}{|c|c|c|c|c|c|}
\hline & & A. nickelii & $\begin{array}{l}\text { Arisarum } \\
\text { vulgare }\end{array}$ & $\begin{array}{l}\text { A. elongatum } \\
\text { subsp. elongatum }\end{array}$ & A. orientale \\
\hline \multirow[t]{2}{*}{$:$} & $\begin{array}{l}\text { Endodermiste } \\
\text { kalınlaşma }\end{array}$ & Belirgin değil & $\begin{array}{l}\text { Kaspari } \\
\text { şeklinde }\end{array}$ & Belirgin değil & 3 yönlü \\
\hline & Ksilem kolu sayısı & 7-8 kollu & 5 kollu & 5 kollu & 4 kollu \\
\hline \multirow{2}{*}{ 喥 } & Rafit demetleri & Gözlenmedi & Gözlendi & Bulunur & Belirtilmemiş \\
\hline & Destek doku & Kollenkima & Kollenkima & Sklerenkima & Sklerenkima \\
\hline \multirow{3}{*}{ 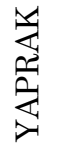 } & Yapısı & bifasiyal & unifasiyal & bifasiyal & bifasiyal \\
\hline & Rafit demetleri & Gözlendi & Gözlenmedi & Belirtilmemiş & Bulunur \\
\hline & Aerenkima & Gözlenmedi & Bulunur & Bulunur & Bulunur \\
\hline
\end{tabular}

Sonuç olarak bu çalışmada, çalışılan türlerin köklerinde iletim demetlerinin ve endodermin yapısı, gövdede köşe kollenkimasının bulunuşu, yaprak mezofilinin yapısı, rafit kristallerin bulunuşu ve yapısı ile yaprakta aerenkimanın bulunması bu türler için ayırt edici anatomik özellikler olarak tespit edilmiştir. Aerenkimanın bulunuşu yaşanılan habitatın su açısından zengin olduğunu göstermektedir. Arisarum ve Arum cinslerine ait türlerinin zehirli etkileri yanında tıbbi kullanım alanları da mevcuttur. Çalışma sonucunda elde edilen bulgular ileride gerçekleştirilecek olan farmasotik ve ayrıntılı anatomik çalışmalar için kaynak oluşturacaktır.

\section{TEŞEKKÜR}

$\mathrm{Bu}$ çalışma "2.Uluslararası Kazdağı ve Edremit Sempozyumu”nda poster bildiri olarak sunulmuştur.

\section{KAYNAKLAR}

Algan G 1981. Microtechnics for the Plant Tissues. Firat University, Science and Art Faculty, Publication Number: 1, İstanbul, 94 p.
Alpınar K 1985. Batı Türkiye'de Arum L. ve bu türlerin nişasta ve protein miktarları, Doğa Bilim Dergisi, 9(3): 473-483.

Alpınar K, Karayiğit N, İmre Z 1996. Türkiye'de Yetişen Bazı Arum L. Türlerinin Zehirliliği Hakkında Ön Araştırma (I), XIII. Ulusal Biyoloji Kongresi 17-20 Eylül, İstanbul.

Anonim 2017. The Plant List (2013). Version 1.1. Published on the Internet; http://www.theplantlist.org/ accessed 1st January (Erişim tarihi: 09.05.2017).

Birdsey MR 1955. The morphology and taxonomy of the genus Syngonium (Araceae). University of California. Unpubl. Ph.D. Thesis.

Dahlgren RMT, Clifford HT 1982. The Monocotyledons. A Comparative Study. Academic Press, New York.

Dalitzsch M 1886. Beiträge zur Kenntnis der Blattanatomie der Aroideen. Bot. Centralbl. 25: 153-156.

Davis PH 1984. Flora of Turkey and the East Aegean Islands. Edinburgh Univ. Press, Edinburgh, vol 8. 
Davis PH, Mill RR, Tan K 1988. Flora of Turkey and the East Aegean Islands. Edinburgh Univ. Press, Edinburgh, vol 10.

Fahn A 1990. Plant Anatomy. 4th ed. Pergamon Press, Oxford, New York.

Genua JM, Hillson CJ 1985. The occurrence, type and location of calcium oxalate crystals in the leaves of fourteen species of Araceae, Annals of Botany, 56: $351-361$.

Güner A, Özhatay N, Ekim T, Başer KHC 2000. Flora of Turkey and the East Aegean Islands. (Suppl 2) Edinburgh Univ Press Vol. 11, Edinburgh.

Güner A, Akyıldırım B, Alkayış MF, Çıngay B, Kanoğlu SS, Özkan AM, Öztekin M, Tuğ GN 2012. Türkçe Bitki Adları: Güner A, Aslan S, Ekim T, Vural M, Babaç MT Edlr. Türkiye Bitkileri Listesi (Damarlı Bitkiler). Nezahat Gökyiğit Botanik Bahçesi ve Flora Araştırmaları Derneği Yayını, 263.s İstanbul.

Kadri H, Zeghad F, Djilani A 2013. Antioxidant activity and polyphenol content of methanol extracts from Arisarum vulgare, Planta Medica 79 - PI51.
Kandemir N 2008. Ordu çevresinde yayılış gösteren Arum L. (Araceae) cinsinin bazı türleri üzerinde morfolojik ve anatomik incelemeler. Biyoloji Bilimleri Araştırma Dergisi, 1: 37-43.

Keating RC 2003. Anatomy of the Monocotyledons. IX. Acoraceae and Araceae. (Series editors: Gregory M, Cutler DF.) Oxford, UK: Oxford University Press.

Keating RC 2004. Systematic occurrence of raphide crystals in Araceae. Annals of the the Missouri Botanical Garden, 91: 495- 504.

Mayo SJ, Bogner J, Boyce PC 1997. The genera of Araceae. Kew, London: Kew Publishing.

Metcalfe CR, Chalk L 1983. Anatomy of the Dicotyledons. Oxford Univ. Press, Oxford, vol. 1.

Selvi S, Erdoğan E, Daşkın R, 2008. Morphological, anatomical and ecological studies of Hyacinthella lineata (Liliaceae), Ecology, 17: 24-32.

Tieghem P van 1867. Recherches sur la structure des Aroidées. Annales des Sciences Naturelles; Botanique sér. 5, 6: 72-210.

Yentür S, 1995. Bitki Anatomisi. İstanbul Üniversitesi Yayınları, No: 3808, Fen Fak. Yay. No: 227, İstanbul. 